\title{
Bilateral Musculus Infraclavicularis
}

Felix Wehrli ${ }^{1}$, Mathias Bergmann ${ }^{2}$ and Richard W Nyffeler ${ }^{3 *}$

${ }^{1}$ Nambour General Hospital, Australia

${ }^{2}$ Department of Anatomy, University of Bern, Switzerland

${ }^{3}$ OrthopädieSonnenhof, Switzerland

Submission: March 05, 2017; Published: September 22, 2017

*Corresponding author: Richard W Nyffeler, OrthopädieSonnenhof, Buchserstrasse 30, 3006 Bern Switzerland, Tel: +41 313581292 , fax: +4131358 19 22, Email: richard.nyffeler@bluewin.ch

\section{Abstract}

We describe a rare accessory pectoral muscle that was found during surgery on both sides in a 78-year old female patient treated with reverse total shoulder prostheses. The muscle has its origin at the middle third of the clavicle, is separated from the clavicular part of the pectoralis major, crosses the cephalic vein and inserts on the fascia of the deltoid muscle. The muscle is triangular in shape with the apex at the origin and the base at the insertion.

Keywords: Pectoral; Muscle; Human; Anatomy; Accessory; Supernumerary

Introduction

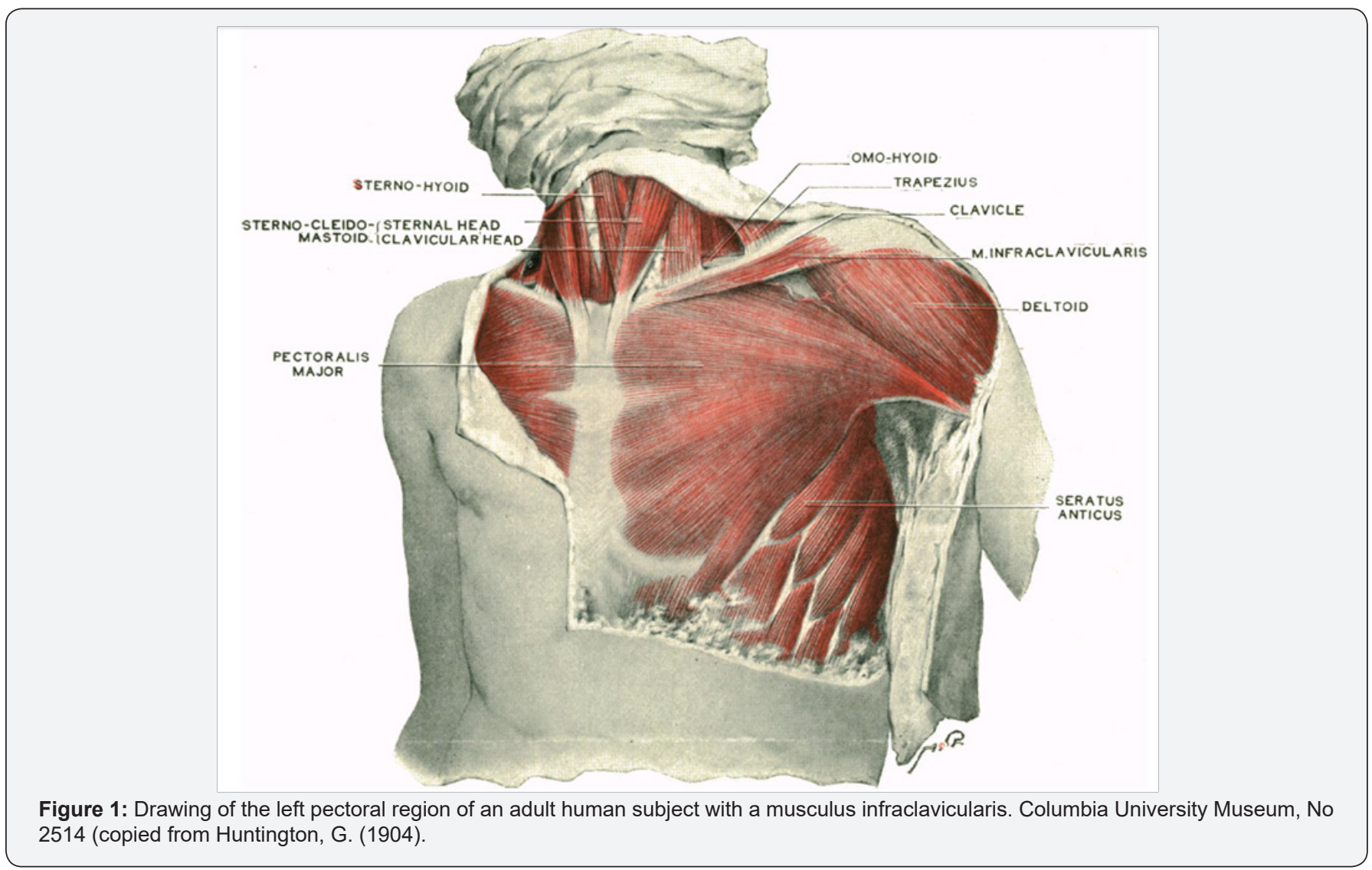


Anatomists have described several supernumerary muscles around the shoulder. They have been classified by Huntington [1] according to their topographic position into: A) deep supernumerary muscles, situated in the space between the pectoralis major and minor, and B) superficial supernumerary muscles, placed superficially to the pectoralis major. One of them is the musculus infraclavicularis, first described by Testut in 1884 and since then mentioned only a few times in the international literature (1,2) (Figure. 1). The last report dates from (3). Accordingly, only drawings have been published. We present a photograph of a musculus infraclavicularis, which was observed during surgery in a Caucasian female.

\section{Case Report}

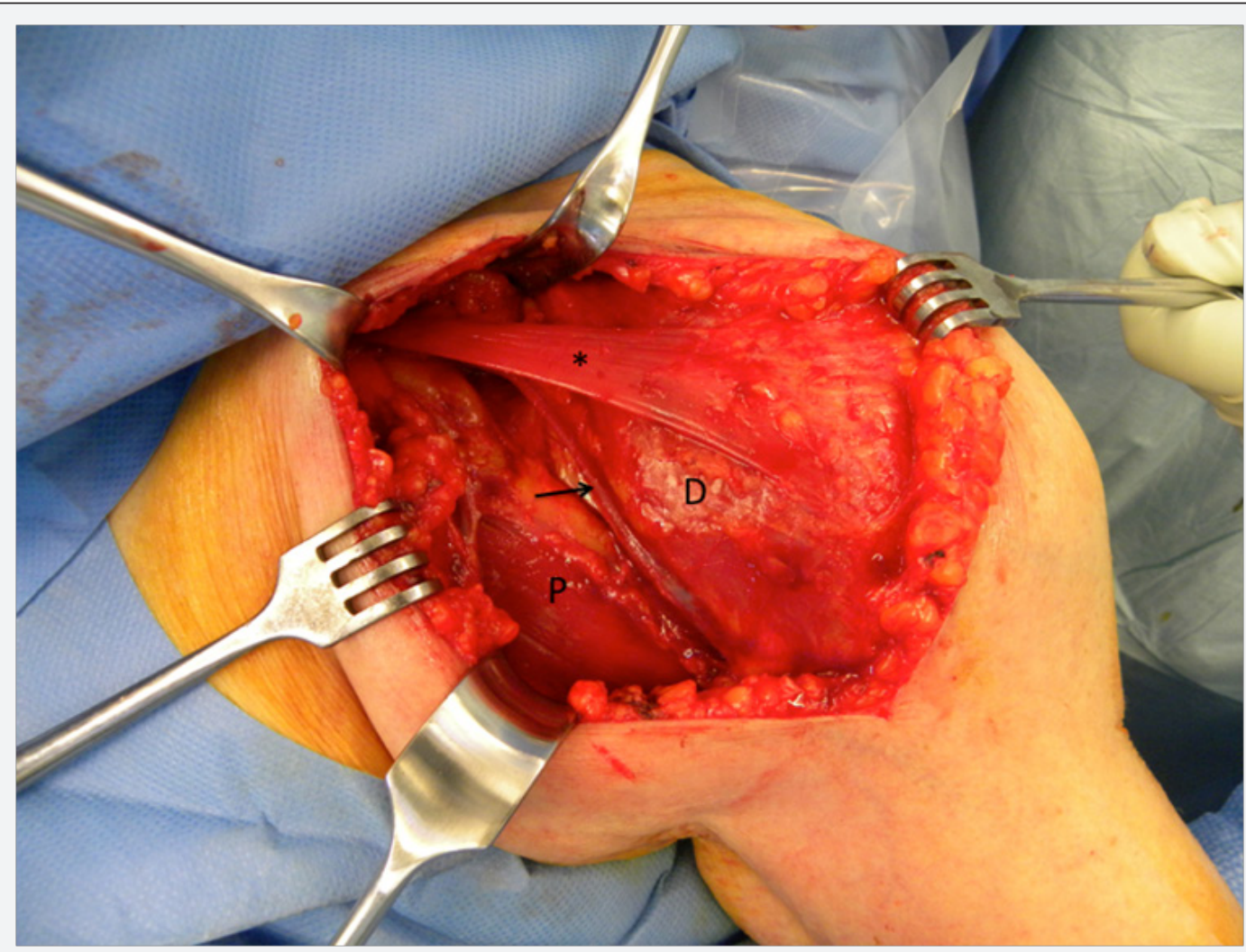

Figure 2: Deltopectoral approach to the left shoulder showing a musculus infraclavicularis (asterisk) in a 78-year-old female patient. The muscle originates from the clavicle, crosses the cephalic vein (arrow) and inserts on the deltoid muscle (D). It is superior to the pectoral major muscle $(P)$.

A 78-year-old female with the diagnosis of a massive nonreparable rotator cuff tear and associated glenohumeral arthritis on both sides was treated with reverse total shoulder prostheses. The shoulders were operated on at an interval of 7 months using the same standard surgical procedure. During dissection of the delto-pectoral interval a thin, fan shaped superficial muscle crossing the operative field from medial to lateral was discovered. It originated from the anterior-inferior aspect of the middle third of the clavicle, superficially to the clavicular part of the pectoralis major, crossed the cephalic vein and inserted into the fascia of the deltoid muscle (Figure. 2). The whole muscle consisted of fleshy fibres and had no macroscopically visible tendinous portion. The length of the muscle measured approximately $9 \mathrm{~cm}$; the width increased from $1 \mathrm{~cm}$ at the origin to $3 \mathrm{~cm}$ at the insertion and the thickness was constant and approximately $2 \mathrm{~mm}$. The neurovascular pedicle could not be identified. As described by Huntington, the proximal part of the delto-pectoral interval was wider than usual. On the right side the accessory muscle was carefully detached from its insertion on the deltoid and sutured to the pectoralis major in order to facilitate access to the shoulder. On the left side it was retracted superiorly with use of a retractor, and it was still intact at the end of the procedure. No other family member of the patient had a shoulder surgery; it is therefore not known, if the abovedescribed muscle exists in other persons related to the patient. At the latest follow-up the patient was pain free and had a good shoulder function on both sides.

\section{Discussion}

Different accessory muscles around the shoulder girdle have been described: the pectoralis quartus muscle $(1,4,5]$, the sternoclavicularis muscle $(1,6)$, the axillary arch $(7,8)$, the sternalis muscle (9), the chondroepitrochlearis muscle $(10,11)$ and the infraclavicularis muscle (12) (Table I). The infraclavicularis muscle described by Testut has its broad origin at the anterior boarder of the clavicle and inserts in the 


\section{Global Journal of Archaeology \& Anthropology}

aponeurosis of the pectoral and deltoid muscle. The muscle infraclavicularis initially described, because it has only a small presented in this paper is slightly different from the musculus insertion and no tendinous extension.

Table 1: Listing of the supernumerary muscles of the pectoral region published in the international literature.

\begin{tabular}{|c|c|c|c|}
\hline Muscle & Author & Origin & Insertion \\
\hline $\begin{array}{l}\text { Chondro coracoideus ventralis } \\
\text { (Pectoralis minimus) }\end{array}$ & Gruber & first rib and cartilage & coracoid process and subdeltoid aponeurosis \\
\hline Pectoralis tertius & Macalister & upper ribs & $\begin{array}{c}\text { coracoid process and crest of tuberculum } \\
\text { majus }\end{array}$ \\
\hline Pectoralis quartus & Macalister & lower ribs & proximal humerus \\
\hline Prae-clavicularis & Gruber & $\begin{array}{l}\text { sternoclavicular joint capsule, mid third } \\
\text { anterior clavicle }\end{array}$ & acromion \\
\hline Tensor semi-vaginae & Gruber & $\begin{array}{l}\text { first and/or second costal cartilage and } \\
\text { sternum }\end{array}$ & deep fascia of the deltoid \\
\hline Sterno-clavicularis anticus & Bryce & $\begin{array}{l}\text { anterior sternoclavicular ligament, } \\
\text { Cartilage of the first rib }\end{array}$ & lateral end of the clavicle \\
\hline Axillary arch & Wilson & latissimus dorsi & $\begin{array}{l}\text { pectoral major muscle, coracobrachialis or } \\
\text { short head of biceps }\end{array}$ \\
\hline Sternalis & Cunningham & sternum, infraclavicular area & $\begin{array}{l}\text { rectus sheet, costal and external oblique } \\
\text { aponeurosis }\end{array}$ \\
\hline Infraclavicularis & Testut & middle third of clavicle & fascia of deltoid \\
\hline
\end{tabular}

Normally, skeletal muscles have their origin and insertion on two distinct bones and their function is to move a joint. The muscle presented in this paper is different. It originates from a bone and inserts on a muscle fascia. Testut and Le Double called it "tenseur de l'aponévrose sous-claviculaire antérieure". The muscle is very thin and absent in the big majority of individuals. We therefore think that it has no specific function. As suggested by Huntington it is probably rather a fortuitous variation and the result of a disturbance of the normal processes of pectoral muscular development.

Del Sol and Vasquez stated that the important aspect of supernumerary pectoral muscles is that they might confuse the surgeon or make the surgical access to the content of the axillary fossa more difficult (13). The infraclavicularis muscles presented in this case report were superficial and easy to recognize during careful dissection of the delto-pectoral interval. They aroused our interest but caused no additional problems for the identification of the anatomical landmarks or the implantation of the prostheses.

\section{Conflict of interest}

No benefits in any form have been received or will be received from a commercial party related directly or indirectly to the subject of this article. The authors have no conflict of interest.

\section{References}

1. Huntington GS (1904) The derivation and significance of certain supernumerary muscles of the pectoral region. J AnatPhysiol (39): 1-54.
2. Le Double AF (1897) Traité des variations du système musculaire de l' homme, Schleicher Frères, Paris, France.

3. Eisler P (1912) Die Muskeln des Stammes, Fischer, Jena, Germany.

4. Macalister A (1872) Muscular anomalies in human Anatomy, Trans Roy Irish Academy.

5. Birmingham A (1889) Homology and innervation of the achselbogen and pectoralis quartus and the nature of the lateral cutaneous nerve of the thorax. J Anat 23: 206-223.

6. Bryce TH (1899) Note on a group of varieties of the pectoral sheet of muscle. J Ant Physol 34: 75-78.

7. Cunningham DJ (1888) The musculus sternalis. J AnatPhysiol 22: 391407.

8. Wilson JT (1888) Observations on the innervations of axillary muscular arches (Achselbogen) in man, with remarks on their homology suggested by comparative considerations. J Anat 22: 294-299.

9. Yap SE (1921) Musculus Sternalis in Filipinos. Anat Rec (21): 353-371.

10. Bergmann, Thompson, Afifi, Saadeh (1988) Compendium of Human Anatomic Variations, Baltomore: Urban \&Schwarzenberg, München, Germany.

11. Flaherty G, O`Neill MN, Folan-Curan J (1999) Case Report: Bilateral occurrence of a chondroepitrochlearis muscle. J Anat 194: 313-315.

12. Testut L (1884) Les anomalies musculaires chez l'homme, Masson, Paris, France.

13. Del Sol M, Vasquez B (2009) Anatomical and Clinical Considerations of the Pectoralis Tertius Muscle in Man. Int J Morphology 27(3): 715-718.

14. Gruber W (1860) Die supernumeraeren Brustmuskeln des Menschen. Mem. de l'Acad Imp de St Petersbourg : 10. 


\section{Your next submission with Juniper Publishers} will reach you the below assets

- Quality Editorial service

- Swift Peer Review

- Reprints availability

- E-prints Service

- Manuscript Podcast for convenient understanding

- Global attainment for your research

- Manuscript accessibility in different formats

( Pdf, E-pub, Full Text, Audio)

- Unceasing customer service

Track the below URL for one-step submission https://juniperpublishers.com/online-submission.php 